\title{
PELATIHAN PENGGUNAAN PREZI SEBAGAI MEDIA PEMBELAJARAN YANG MENYENANGKAN
}

\author{
Muhroji $^{1}$, Farida Kurniawati Utami ${ }^{1}$, Nashrulloh Rafif Izzuddin ${ }^{1}$, \\ Amelia Wahyu Sejati ${ }^{1}$, Muhamad Taufik Hidayat* ${ }^{1}$ \\ ${ }^{1}$ PGSD, Universitas Muhammadiyah Surakarta \\ email:*muh231@ums.ac.id
}

\begin{abstract}
Abstrak: The purpose of this community service is to provide knowledge and training related to the Prezi learning media to principals and teachers of MIM Parakan. The material provided is an introduction to Prezi learning media, how to register a Prezi account, how to install Prezi, and how to use and create a learning media from Prezi. The method used is lecture, question and answer, and direct practice. Evaluation is carried out by distributing knowledge and motivation questionnaires and product checklists to participants. In general, participants stated that the training schedule and time were right. On average the participants were satisfied with the topic presented. Although some of the participants' expectations were not fulfilled due to several obstacles such as internet connections and laptops that were less supportive. However, the results of the evaluation indicate that the participants were well trained in the tone of increased knowledge and motivation. In addition, the participants' simple work was also quite well.
\end{abstract}

Keyword: Prezi Training, Elementary School, Learning Media

\begin{abstract}
Abstrak: Madrasah Ibtidaiyah Muhammadiyah (MIM) Parakan merupakan salah satu yang tengah mempersiapkan diri untuk menjadi sekolah yang unggul dalam tingkatan Sekolah Dasar (SD). Penguasaan guru SD akan Teknologi Informasi dan Komunikasi (TIK) sangat berpengaruh sekali terhadap penguasaan guru SD dalam penggunaaan media pembelajaran Tujuan dari pengabdian masyarakat ini adalah memberikan pengetahuan dan pelatihan terkait media pembelajaran berbasis teknologi Prezi kepada kepala sekolah dan guru MIM Parakan, Karanganyar. Materi yang diberikan adalah pengantar pembelajaran media, cara mendaftarkan akun Prezi, cara memasang dan cara menggunakan pembelajaran dari Prezi. Metode yang digunakan adalah tanya jawab, praktik langsung, dan demonstrasi. Evaluasi dilakukan dengan membagikan angket pengetahuan dan motivasi serta daftar periksa produk kepada peserta. Secara umum, peserta menyatakan bahwa jadwal dan waktu pelatihan sudah tepat. Rata-rata peserta puas dengan topik yang disajikan. Meskipun beberapa harapan peserta tidak terpenuhi karena koneksi internet dan laptop yang kurang mendukung. Namun, ada indikasi bahwa peserta terlatih dengan baik dalam hal peningkatan pengetahuan dan motivasi. Selain itu, karya sederhana dari para peserta juga cukup baik.
\end{abstract}

Kata Kunci: Pelatihan Prezi, Sekolah Dasar, Media Pembelajaran 
Available online at https://jurnal.stmikroyal.ac.id/index.php/jurdimas

\section{PENDAHULUAN}

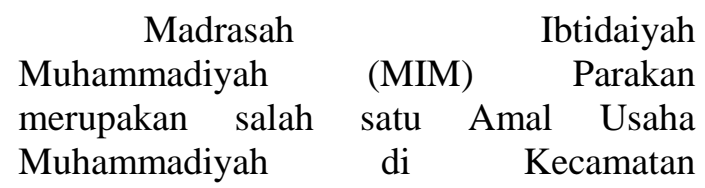

Karanganyar, Kabupaten Karanganyar yang tengah mempersiapkan diri untuk menjadi sekolah yang unggul dalam tingkatan Sekolah Dasar (SD). Potensi yang dimiliki oleh sekolah ini adalah dengan adanya pendidik yang sebagian besar atau keseluruhan adalah guru muda dan fasilitas sekolah yang sudah lengkap. Potensi yang besar dari MIM Parakan tersebut perlu dikelola dan dikembangkan secara baik.

Terkait dengan perkembangan pendidikan pada era milenial ini, seorang guru khususnya akan selalu dituntut untuk mengikuti perkembangan jaman. Salah satu perkembangan jaman saat ini adalah era teknologi. Dimana guru harus menguasai berbagai macam teknologi untuk mengajar maupun meningkatkan keterampilan individual guru. Penguasaan guru SD akan Teknologi Informasi dan Komunikasi (TIK) sangat berpengaruh sekali terhadap penguasaan guru SD dalam penggunaaan media pembelajaran. Hal ini dikarenakan banyak media pembelajaran kontemporer yang berbasis TIK. Oleh sebab itu, kemampuan guru SD dalam menggunakan perangkat TIK sangat penting. Media TIK yang dapat digunakan oleh guru dalam pembelajaran tentunya banyak sekali. Banyak media online maupun offline, software maupun hardware, dan dapat digunakan guru sebagai media pembelajaran. Media online misalnya guru sudah menggunakan fasilitas e-mail untuk sarana pengumpulan tugas, blog untuk memposting bahan-bahan ajar agar memudahkan siswa mendapatkan materi pembelajaran dan membuat berbagai media pembelajaran lainnya.

Berdasarkan hasil wawancara dengan Septina, Guru Madrasah Ibtidaiyah Muhammadiyah (MIM) Parakan, Karanganyar menyatakan bahwa guru di MIM Parakan sebagian besar telah memiliki laptop dan difasilitasi proyektor atau LCD. Namun menurut Septina, perangkat TIK tersebut kurang dimanfaatkan sebagai media pembelajaran, bahkan lebih sering terabaikan. Penggunaan perangkat TIK hanya ketika dibutuhkan dan mendesak saja. Padahal seorang guru SD harus lebih memanfaatkan media tersebut untuk membantu meningkatkan kualitas pembelajaran.

Berdasarkan paparan diatas, akar permasalahan belum optimalnya pemanfaatan media pembelajaran berbasis teknologi serta penggunaan teknologi yang masih kurang. Padahal pembelajaran berbantu teknologi menjadi salah satu keterampilan penting bagi guru SD untuk membantu siswa SD mencapai tujuan pembelajaran. Salah satu perangkat lunak yang potensial sebagai sarana penciptaan media pembelajaran yang menarik adalah Prezi. Prezi merupakan sebuah perangkat lunak untuk presentasi berbasis zoom inzoom out. Prezi pada awalnya dikembangkan oleh arsitek Hungaria bernama Adam Somlai-Fischer sebagai alat visualisasi arsitektur. Misi yang dinyatakan oleh Prezi adalah membuat berbagai ide menjadi lebih menarik. Prezi bisa digunakan sebagai media presentasi yang efektif dalam pembelajaran di SD maupun jenjang di atasnya (Akgün, Babur, \& Albayrak, 2016; Bender \& Bull, 2018; Chou, Chang, \& Lu, 2015; Gonzalez et al., 2011; Mahyuddin, Wati, \& Misbah, 2018; Susanti, Mustadi, Asnimar, \& Susiloningsih, 2019). Oleh karena itu perlu upaya peningkatan keterampilan penggunaan media pembelajaran berbasis teknologi bagi guru MIM Parakan.

Dari analisis situasi dapat diketahui bahwa MIM Parakan mengalami kesulitan dalam memanfaatkan fasilitas sekolah seperti $L C D$ guna menunjang aktivitas pembelajaran. Guru-guru di MIM Parakan perlu dibekali keterampilan dalam memanfaatkan teknologi salah satunya dengan penggunaan media pembelajaran Prezi. Guru-guru perlu diberikan wawasan tentang media pembelajaran Prezi, 
Available online at https://jurnal.stmikroyal.ac.id/index.php/jurdimas

bagaimana cara mendaftar dan membuat media pembelajaran Prezi.

Adapun tujuan yang ingin dicapai melalui kegiatan pengabdian ini adalah memberikan wawasan dan pelatihan penggunaan media pembelajaran Prezi bagi guru MIM Parakan di Karanganyar. Hasil kegiatan pengabdian pada masyarakat ini akan memberikan kontribusi positif terhadap usaha peningkatan kualitas pendidikan, khususnya keterampilan guru dalam menggunakan perangkat lunak Prezi di MI Muhammadiyah Parakan.

\section{METODE}

Kegiatan pengabdian ini dilaksanakan dalam bentuk workshop, dan diikuti oleh Kepala Sekolah dan 24 guru di MI Muhammadiyah Parakan sebagai mitra program pengabdian. Materi yang diberikan meliputi: (1) Media Pembelajaran Prezi, (2) Cara mendaftar Prezi, (3) Cara menginstall Prezi aplikasi Prezi, serta (4) Cara penggunaan dan pembuatan media pembelajaran dengan Prezi. Metode yang digunakan oleh tim pengabdian disesuaikan dengan sesi kegiatan. Rincian metode dicantumkan pada Tabel 1.

Keberhasilan kegiatan pengabdian diukur dengan evaluasi. Evaluasi dilakukan dengan cara menyebarkan angket pengetahuan dan evaluasi serta penilaian produk kepada peserta. Instrumen yang digunakan adalah angket pengetahuan dan motivasi serta daftar cek produk.

Tabel 1. Metode Program

\begin{tabular}{lll}
\hline SESI & METODE & $\begin{array}{l}\text { Instrumen } \\
\text { Evaluasi }\end{array}$ \\
\hline $\begin{array}{l}\text { Pengenalan } \\
\text { Prezi }\end{array}$ & $\begin{array}{l}\text { Ceramah dan } \\
\text { tanya jawab }\end{array}$ & $\begin{array}{l}\text { Angket } \\
\text { pengetahuan } \\
\text { dan motivasi }\end{array}$ \\
\hline $\begin{array}{l}\text { Cara mendaftar } \\
\text { Prezi }\end{array}$ & $\begin{array}{l}\text { Ceramah dan } \\
\text { praktik }\end{array}$ & $\begin{array}{l}\text { Angket } \\
\text { pengetahuan } \\
\text { dan motivasi }\end{array}$ \\
\hline $\begin{array}{l}\text { Cara menginstal } \\
\text { Aplikasi }\end{array}$ & $\begin{array}{l}\text { Ceramah dan } \\
\text { praktik }\end{array}$ & $\begin{array}{l}\text { Angket } \\
\text { pengetahuan } \\
\text { dan motivasi }\end{array}$ \\
\hline $\begin{array}{l}\text { Pembuatan } \\
\text { media } \\
\text { pembelajaran } \\
\text { dengan Prezi }\end{array}$ & $\begin{array}{l}\text { Ceramah, } \\
\text { tanya jawab, }\end{array}$ & $\begin{array}{l}\text { Daftar cek } \\
\text { produk }\end{array}$ \\
\hline
\end{tabular}

\section{PEMBAHASAN}

Kegiatan pengabdian ini dilaksanakan melalui beberapa tahapan, yaitu: (1) Mengurus surat ijin pelaksanaan, (2) Sosialisasi program kepada sekolah mitra MIM Parakan, (3) Penyusunan materi-materi workshop, (4) pelaksanaan program pengabdian, (5) Refleksi workshop.

Setelah memperoleh ijin dari sekolah mitra yang meliputi tempat dan waktu, kemudian tim pengabdian menyusun materi workshop yang meliputi (1) Media Pembelajaran Prezi, (2) Cara Menginstall dan mendaftar aplikasi Prezi, serta (3) Cara penggunaan dan pembuatan media pembelajaran dengan Prezi.

Kegiatan pengabdian masyarakat ini dilaksanakan pada hari Senin, 17 Juni 2019. Lokasi bertempat di MI Muhammadiyah Parakan, Kecamatan Karanganyar, Kabupaten Karanganyar. Kegiatan pengabdian ini dilaksanakan dalam bentuk workshop, yaitu workshop media pembelajaran atraktif berbasis Prezi bagi guru MIM Parakan. Kegiatan worshop dihadiri oleh guru dan kepala sekolah MIM Parakan yang berjumlah keseluruhan 25 peserta.

Rangkaian kegiatan workshop diawali dengan pembukaan serta sambutan oleh kepala MIM Parakan dan salah satu dari tim pengabdian dan dilanjutkan dengan sesi pertama yaitu pengenalan Prezi, cara mendaftar Prezi, cara menginstal Prezi serta pembuatan media pembelajaran dengan Prezi.

\section{Pengenalan media pembelajaran Prezi}

Materi yang disampaikan dalam sesi ini diawali dengan pengenalan secara umum mengenai media pembelajaran khususnya media yang berbasis teknologi. Setelah itu pemateri bertanya jawab kepada peserta mengenai media pengetahuan peserta tentang media pembelajaran berbasis teknologi. Setelah itu pemateri menerangkan media pembelajaran Prezi 
Available online at https://jurnal.stmikroyal.ac.id/index.php/jurdimas

secara khusus, meliputi pengertian Prezi, keunggulan Prezi dan juga manfaat penggunaan media pembelajaran Prezi khususnya dalam penggunaan media pembelajaran untuk jenjang sekolah dasar. Pemateri juga menyampaikan jika MIM Parakan mempunyai potensi yang bagus dalam pengembangan media pembelajaran berbasis teknologi khususnya Prezi karena memiliki fasilitas khususnya LCD dan guru yang masih muda.

Pada sesi ini pula pemateri menyampaikan pengalaman-pengalaman pribadi dalam menggunakan media pembelajaran Prezi khususnya dalam presentasi di kelas maupun mengajar di sekolah dasar.

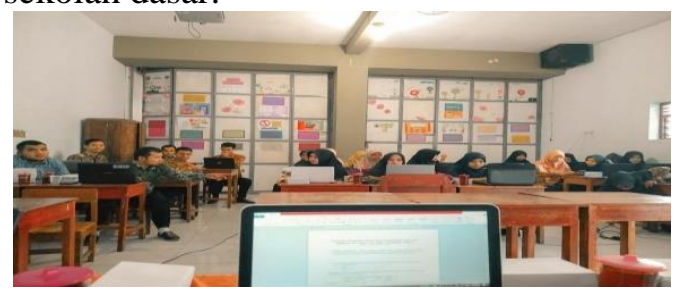

Gambar 1. Pengenalan Media Pembelajaran Prezi

\section{Cara Mendaftar Akun Prezi}

Pada sesi ini pemateri penggunaan Prezi. Salah satunya adalah mendaftar akun Prezi terlebih dahulu. Maka dari itu pemateri membimbing peserta untuk mendaftar akun Prezi. Terkait dengan pendaftaran akun, ternyata ada beberapa peserta yang sudah membuat Prezi sebelumnya. Hanya saja kebanyakan dari mereka sudah lupa bagaimana caranya. Sebelum memulai mendaftar peserta terlebih dahulu menghubungkan laptop dengan koneksi internet. Setelah terhubung peserta diberi petunjuk untuk membuka web browser untuk melakukan pendaftaran akun.

Tahapan pendaftaran akun Prezi: pertama, peserta membuka laman www.prezi.com. Setelah laman terbuka, peserta melakukan pendaftaran dengan mengikuti petunjuk yang ada dimulai dari get started, kemudian memilih akun basic.
Karena ini baru dasar maka peserta diarahkan untuk memilih akun yang free atau tidak berbayar. Setelah itu muncul form pendaftaran, peserta mengisi form pendaftaran menggunakan e-mail maupun akun facebook. Setelah berhasil mendaftar maka peserta langsung diarahkan ke dalam dash board Prezi. Dalam hal ini sebenarnya sudah langsung bisa digunakan untuk melaksanakan pelatihan pembuatan media pembelajaran secara online. Dalam pelaksanaan pengabdian ini, ada beberapa kendala dengan internet dan laptop. Peserta sepakat untuk menginstal aplikasi agar bisa digunakan secara offline dan untuk peserta yang belum bisa mendaftar akun sepakat untuk berbagi laptop dengan teman sebangku. Hal ini dikarenakan ada beberapa laptop yang tidak bisa terhubung ke internet.

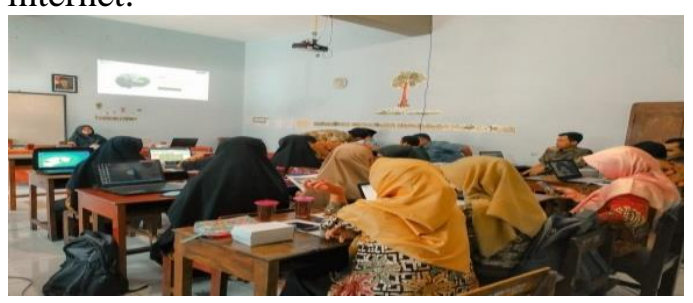

Gambar 2. Mendaftar Prezi

\section{Cara Menginstal Prezi}

Pada sesi ini peserta mendengarkan instruksi dari pemateri untuk melakukan instalasi Prezi. Sebelumnya instalasi Prezi sudah di-copy pada laptop masing-masing peserta. Tahapan dalam menginstal aplikasi ini adalah membuka folder yang berisikan instalasi Prezi, kemudian peserta menginstal aplikasi yang ada. Setelah proses instalasi berhasil, peserta diarahkan kembali ke folder aplikasi untuk meng-copy crack untuk bisa digunakan dalam mode offline. Dalam hal ini, beberapa peserta mengalami kesulitan yang akhirnya pemateri membantu masing-masing peserta untuk melakukan instalasi Prezi. Perbedaan laptop dan spesifikasi menjadi hambatan dalam proses instalasi.

Setelah proses instalasi berhasil, pemateri mengarahkan peserta untuk membuka aplikasi Prezi dan sign in dengan 
Available online at https://jurnal.stmikroyal.ac.id/index.php/jurdimas

akun yang sudah didaftarkan masingmasing.

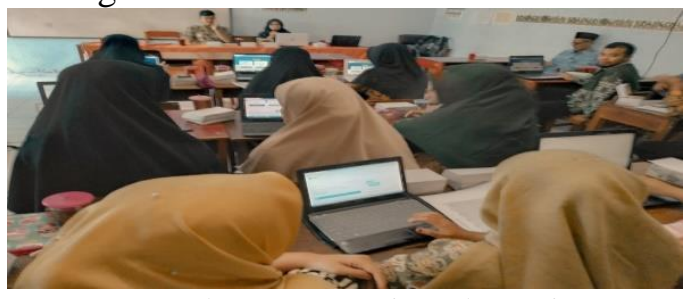

Gambar 3. Menginstal Prezi

\section{Penggunaan dan pembuatan media pembelajaran dengan Prezi}

Pemateri kemudian mengarahkan peserta untuk melihat tampilan pada Prezi masing-masing. Kemudian pemateri menjelaskan mengenai tools beserta fungsinya yang ada didalam aplikasi Prezi kepada peserta. Dalam hal ini peserta mendengarkan penjelasan dari pemateri. Tahap selanjutnya adalah penggunaan Prezi. Peserta diarahkan untuk mengikuti langkah-langkah yang disampaikan oleh pemateri. Beberapa langkah penggunaannya adalah sebagai berikut:

Pertama, membuat new Prezi. Disini peserta diarahkan untuk membuat lembar kerja baru. Setelah itu peserta diajak untuk mengganti background sesuai dengan yang diinginkan. Pemateri juga menjelaskan bahwa sebelum membuat media, peserta harus memikirkan konsep terlebih dahulu sehingga nantinya peserta tidak akan kesulitan untuk membuat media.

Kedua, menghapus frame dan menggantinya dengan frame baru. Langkah selanjutnya peserta diajarkan untuk menghapus frame bawaan dan kemudian menggantinya dengan frame yang baru. Caranya yaitu dengan mengklik pada frame dan kemudian klik delete. Sebagian besar peserta bisa memahami dan melakukan dengan baik. Untuk memasukkan frame yang baru, beberapa peserta masih bingung untuk menggunakan tools yang ada. Kemudian dengan bimbingan dari pemateri peserta akhirnya bisa mengganti frame.

Ketiga, mengunggah gambar yang akan jadi tampilan depan presentasi Prezi. Cara melakukan langkah ini adalah dengan menjelaskan kepada peserta bahwa gambar yang akan ditampilkan ini nanti akan menjadi tampilan depan, sehingga gambar yang diunggah sebisa mungkin bisa sesuai dengan materi yang akan dibuat. Beberapa peserta menanyakan kepada materi tentang materi dan gambar yang sebaiknya dibuat. Dalam hal ini langkah yang digunakan yaitu mengarahkan peserta untuk klik insert > image dan tinggal memilih gambar dari komputer. Peserta dapat melakukan dengan tanpa hambatan.

Keempat, membuat teks judul pada presentasi Prezi. Dari penjelasan pemateri, para peserta sudah cukup paham untuk menjalankan tools untuk membuat teks judul presentasi yang disesuaikan dengan materi yang akan dibuat. Kelima, menambahkan frame baru. Langkah selanjutnya yatu menambahkan frame baru dengan cara yang sama seperti sebelumnya, sehingga peserta sudah bisa melakukannya. Dalam hal ini peserta sudah mulai mengerti fungsi dari masing-masing tools dan dapat menggunakannya dnegan baik.

Keenam, menambahkan shape pada presentasi Prezi. Shape bisa digunakan untuk penomoran. Beberapa peserta menanyakan untuk menggunakan penomoran. Kemudian pemateri menjelaskan bahwa shape bisa digunakan untuk penomoran. Dalam hal ini peserta sudah mulai termotivasi dengan ide-ide yang kreatif. Ketujuh, menuliskan konten untuk tiap slide presentasi Prezi. Sebagian besar peserta sudah bisa menuliskan konten dengan baik.

$\begin{array}{rlr}\text { Setelah } & \text { mengajarkan } & \text { kepada } \\ \text { peserta } & \text { cara } & \text { penggunaan aplikasi }\end{array}$ selanjutnya peserta diberi waktu selama kurang lebih 60 menit untuk membuat media presentasi sederhana menggunakan Prezi. Setelah waktu dirasa sudah cukup, tim pengabdian mencoba melihat satu persatu progress yang dilakukan masingmasing peserta. Dalam hal ini bisa dilihat perkembangan atau progress masingmasing setiap peserta berbeda. Ada yang sudah menerapkan keseluruhan cara yang telah diajarkan da nada yang baru sampai 
Available online at https://jurnal.stmikroyal.ac.id/index.php/jurdimas

dalam tahap penggunaan cara tertentu.

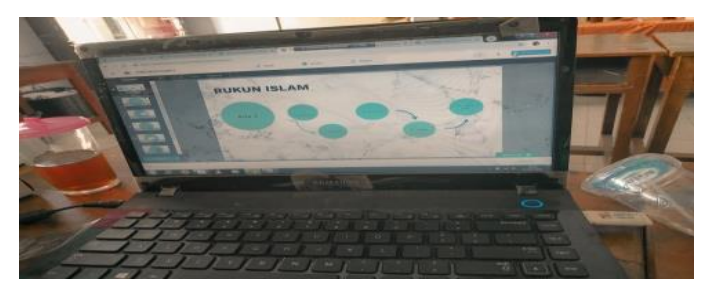

Gambar 4. Pembuatan media pembelajaran dengan Prezi

\section{Evaluasi Peserta}

Dari hasil angket pengetahuan diketahui bahwa secara umum peserta cukup baik dalam memahami media pembelajaran Prezi. Peserta memahami jika menguasai media pembelajaran dapat meningkatkan keterampilan guru dalam mengajar. Sementara itu berdasarkan angket motivasi diketahui bahwa peserta merasa mampu untuk menggunakan media pembelajaran berbasis teknologi Prezi untuk mengajar dan memilih Prezi untuk dijadikan media pembelajaran dan yakin jika siswa MIM Parakan akan senang dengan pembelajaran yang menggunakan media pembelajaran Prezi. Terakhir, terkait produk workshop beberapa sudah tercapai berupa media pembelajaran berbasis Prezi. Hanya saja masih banyak lagi yang harus dipelajari peserta untuk benar-benar bisa menggunakan aplikasi Prezi dan membuat media pembelajaran yang lebih kreatif.

\section{SIMPULAN}

Secara umum peserta sepakat jika penjadwalan workshop sudah baik, alokasi waktu sudah baik, keseimbangan antara teori dan praktik juga sudah tepat. Peserta sepakat jika harapan dan tujuan dari workshop hampir seluruhnya terpenuhi. Hasil evaluasi menunjukkan bahwa terjadi peningkatan pengetahuan, sikap dan ketrampilan peserta terhadap aplikasi Prezi.

\section{DAFTAR PUSTAKA}

Akgün, Ö. E., Babur, A., \& Albayrak, E. (2016). Effects of Lectures with PowerPoint or Prezi Presentations on Cognitive Load, Recall, and Conceptual Learning. International Online Journal of Educational Sciences. https://doi.org/10.15345/iojes.2016.03 .001

Bender, C., \& Bull, P. (2018). Using Prezi to Motivate Middle School Science Students. I-Manager's Journal on School Educational Technology. https://doi.org/10.26634/jsch.7.3.1669

Chou, P. N., Chang, C. C., \& Lu, P. F. (2015). Prezi versus PowerPoint: The effects of varied digital presentation tools on students' learning performance. Computers and Education.

https://doi.org/10.1016/j.compedu.201 5.10.020

Gonzalez, A., Sonstrom, S., Silvey, P., Boscarino, M., Shea, I., Trusz, J., ... Lindstrom, S. (2011). Workshop Summaries: Excite Students with Tech. Learning Languages.

Mahyuddin, R. S., Wati, M., \& Misbah, M. (2018). Pengembangan Media Pembelajaran Fisika Berbasis Zoomable Presentation Berbantuan Software Prezi Pada Pokok Bahasan Listrik Dinamis. Berkala Ilmiah Pendidikan Fisika. https://doi.org/10.20527/bipf.v5i2.358 8

Susanti, A., Mustadi, A., Asnimar, \& Susiloningsih, E. (2019). The Improvement in Poetry Writing Skills by Using Prezi in the Primary School. Mimbar Sekolah Dasar, 6(1), 92-104. Retrieved from http://ejournal.upi.edu/index.php/mim bar/article/view/14557 